\title{
Drawing or Design? Contribution to the definition of designology ${ }^{1}$
}

\author{
Francisco Providência
}

\section{PRESENTATION}

As far as transforming data into information and information into knowledge are concerned, design adopts a relevant mediator role. Data lack interpretation in order to ascend to information. Interpreting means to take control over data, understand them and, consequently, extrapolate new knowledge.

Drawing is interpreting. Whenever drawing overcomes representational dimension to a projectual one, there will be knowledge. Actually, representational drawing does not exist without interpretation; choosing what to draw by selecting a tiny part of what we observe, is a good example. Therefore, it is the knowledge of a thoughtful practice on drawing that I would like to convene here.

\section{WHAT IS DESIGN?}

While attending the Communication Design degree at the Fine Arts Faculty of the University of Porto (1980-1985), nobody questioned the meaning of Design, although there were many producing it. Design justified itself with the need of bringing order into the disorder of reality, contributing to solving problems in a user-centred manner. Designers believed they could discipline, functionalize or even "cure" society. This preventive idea that design can (or should) intervene to cure, (to cure bad taste or social inequalities), would persist until nowadays, as a social functionalist model.

At that beginning of the 1980s, the first signs of post-modern revolution appeared, bringing new questions to the ontological definition of the subject, seeming to blur boundaries between anthropology, art and design. We can say that the need to establish boundaries (simple and solid) seems to justify a status of seizure towards the future _ as stated by Worringer in his "abstraction and empa-

1 Communication delivered in Natal (Congresso CIDI, Congresso Internacional de Design de Informação, Universidade Federal do Rio Grande do Norte, Natal 2017). Translation by Rita Afreixo Silva (2018). 
thy" theory, regarding the emergence of the expressionist aesthetics (starting from abstraction), product of a time threatened by war, counter to Portugal economic and social optimism on the eve of entering the European Community. To Worringer, in opposing the abstract and critical expressionism, uncritical and empathic realism from prosperous societies at times of peace emerged, as one could perceive in Europe at the end of the 20th century. But I must confess that that need of "circumventing", of delimiting, would remain in my spirit, searching for the ontological boundaries of design, although constituting a theme outside the agenda, by opposing the dominant idea that design will accomplish itself in the utmost hybridisation with many, if not all, subjects. One design liquefaction (as Bauman would say), bringing ambiguity to speech, to teaching, to organizations and media. Without the fundamental knowledge on designers' identity and what they can, specifically, offer, it will be difficult to define and to state this professional and scientific area, either towards academy or towards society.

If in the 1980s of last century one was already doubting Design, nowadays its definition seems even more distant, associated with countless domains and concepts, at times conflicting, that seem driven more by economic, cultural and social speculation of that root than by the clarification and benefit of its worth. The word Design has been disposed by the market. For that reason, Design, in Spain, as Anna Calvera said full of humour, is the name one gives to something expensive that we do not know yet what it is for.

Through history Design has acquired a long track of aesthetic, technical, social and commercial associations. If, on the one hand, design is mentioned about almost everyting, on the other hand it is also true that the extension of its domain seems to mean less and less in depth, exposing itself to a certain inoperative ambiguity. Margolin also recognizes, with concern, a general crisis in Design "[...] The fact is there is a crisis in design because of its multifaceted activities on practice, research, speech and education" (Margolin, 2013, p. 404). In Design Dictionary (Erlhoff and Marshall, p. 2008), we can count more than 40 design supspecies $^{2}$ (such as Eco design, Social design or Food design...). If design has

2 Design Dictionary (2008), 48 declinations from Design: design against crime, design and politics, design criticismo, design education, design history, design management, digital design, eco design, engineering design, environmental design, ergonomics design, fashion design, food design, furniture design, futuristic design, game design, social design, gender design, graphic design, green design, industrial design, information design, interface design, interior design, jewelry design, landscape design, lighting design, mechatronic design, media design, packaging design, participatory design, public design, radical design, registered design, retail design, retro design, safety design, 
been encountering in science extraordinary reasons of multidisciplinary association, giving origin to new production formats, science has also found in design a transdisciplinar means of accomplishment, conception and communication as it is possible to observe through the multiple Design thinking applications, serving innovation management. Design thinking, nowadays diffused in every design schools, seems to be the best recipe to ensure creativity amongst academy and organizations, colectivelly integrating teachers and students into a process led by management, with the purpose to distil (tacit) knowledge.

\section{DRAWING AS A METAPHOR}

In the course of my professional activity, either as a designer or as a teacher (activities that always have crossed), I soon searched for answers to the definition of this activity with deep roots in drawing. I understood, afterwards, that Design's etymology came from Drawing. But I also understood that the main source of entropy in the representation of Design derived from the Anglo-Saxon division between its representational and projectual dimensions.

Design stands for project (in english) although, with a latin origin from disegno (drawing and plan or project), an italian term appropriated by english language, between the 16th and the 17th centuries. A part of design's Tower of Babel, of the confusion generated by so many different languages, comes from that ambiguity created by the english division between draw and design (drawing and project).

When Francisco de Holanda (1517-1585) was sent to Rome to learn Drawing (between 1538 and 1541) as a D. João III fellow, he did not simply go to understand the masters' drawing (enjoying Michelangelo's innaccessible company), but also to become aware of "Da Sciencia do Desegno", on which he would theorise later on, as a resource for invention, as a means to materialize ideas and build the artificial: "invent, figure or imagine what does not exist yet, so that it is and it will be ${ }^{3}$ ", acknowledging in this the announcement of what we now designate by Design. For that (according to neo-platonic thinking) it was necessary to be in harmony with the Creator (from where all novelty comes) and to master the speed of drawing in scratch capable to register the lightning in each creative spark.

screen design, service design, set design, slow design, sound design, strategic design, streamline design, textile design, transportation design, universal design, urban design, users design, web design.

3 HOLANDA, Francisco de (1985). Da Ciência do Desenho. Lisboa, ed. Livros Horizonte. 
"The first lines or strokes done (...) drawn with great mastery and quickly, (... that) incorporate the idea (...) of what we want to do, and organize the drawing"

Back then, scratch was seen by Holanda, as nowadays by Álvaro Siza, as an instrument to register synthetically the ephemeral idea (the origin of poetic scien$\mathrm{ce}^{5}$ ) where the resolution of the complexity of the project is founded. It is, though, this drawing (or disegno) that gave origin to Design, achieving what previously only existed in imagination (representation and project).

It is possible to identify, between the latin languages that have in desenho (portuguese), diseño (castilian) and disegno (italian) a common etimology that has distanced itself from the remote origin of Design, rooted in the intentionality of the plan that, through the Anglo-Saxon approach, assumed the exclusive meaning of "project". Drawing, that reunited representation and antecipation, poetic language and technical project, the author (autobiographically conditioned) and his will (morally projected), was divided and partially represented through the project (design).

But if to the Project it is possible to ignore or exclude its operator subjectivity, it will be harder when talking of drawing. As Alberto Carneiro ${ }^{6}$ noted, "who draws, draws himself". In this self-reflective possibility of drawing there will be also the potential of self-interpretation to which design should not resign. On the other hand, I understand that it is in the Drawing phenomenon that stands Design's ontology. Drawing is the result of the action of a draughtsman (operator agent), driven by an intention (or will), materialised through a representation instrument (pencil on paper or other). That is why there is always an author, an intention and an instrument in drawing, through which articulation of meaning circulates: "There is no drawing without will, nor drawing that does not carry a plan” (Francisco Providência).

Drawing practical intentionality acquires a form and that for is a communication (rhetorical) value in itself. For that reason it constitutes a plan. As I learned from Adorno, form is the true content of works of art; form, in itself, not what they convey. That is to say, what one understands as true content in the painting "Les demoiselles d'Avignon" by Picasso will not be the reference to african art or catalan prostitution, but cubism in itself obvious in its morphology.

4 Idem, ibidem, page 45.

5 Poietica, related to the production or the arts of creative production (from the gr. "poie" or eclosão). (Dagobert D. Runes, Dicionário de Filosofia, Lisboa, Editorial Presença, 1990).

6 Alberto Carneiro (1937 - 2017), portuguese plastic artist and sculptor, teacher of Drawing at Faculdade de Arquitetura da Universidade do Porto. 
The identification of a trilogy grounded on the agent (author), the intention (programme) and the means (technology) ${ }^{7}$, that I have been defending as an ontological proposal for Design, correlates with the one sustained by Vitruvius, when proposing architecture as founded on beauty (Vetustas), on functionality (Utilitas) and resistance (Firmitas) (RUA, 1998, p. 16)

Beauty, to the architect of the imperial military regime, was mainly the stylistic canonical domain (the domain of laws and models); Functionality related to the adequacy of the architectural object to the expected uses and performances; and Resistance, to the techniques and construction processes, upon which the durability would depend. These conditions were universally accepted by the subject are still an evaluation requirement to the awardees of Pritzker family ${ }^{10}$ (in Pritzker Award, recognised since 1979 as the "Architecture Nobel").

Born twenty years later, Seneca ${ }^{11}$, establishes (from Aristotle) what Vitruvius, in a practical way, particularized for Architecture:

"The cause (of things) may be considered from three points of view (:...) matter itself without which nothing can be produced (...), the craftsman (who works

7 Francisco Providência, "Algo más que uma hélice" in CALVERA, Anna (ed) (2013). Arte? Diseño? Nuevos capítulos em una polémica que viene de lejos. Barcelona, ed. Gustavo Gili, pp 195-214.

8 Marcos Vitruvius Pollio, engineer / architect of the roman army, was born in the 1st century BC leaving as legacy the first theoritecal treaty on architecture, designated by him as De Architectura, compiling in 10 volumes texts and drawings arguing that "such constructions must seek for safety, utility and beauty...". This work, probably written between 27 and 23 BC, was re-edited in Rome in 1446 and, from then on, released and translated into several languages, mainly since the 16th century, as a support to the Renaissance. His architecture treaty is edited in portuguese by Maria Helena Rua.

9 RUA, Maria Helena (1998). Os dez livros de arquitectura de Vitrúvio (Corrigidos e traduzidos recentemente em Português, com notações e figuras). 1. ed. Lisboa: Departamento de Engenharia Civil, Instituto Superior Técnico. ISBN: 129.248/98.

10 Pritzker Architecture Prize, awarded to brazilians Oscar Niemeyer (1988) and Paulo Mendes da Rocha (2006) and portuguese Álvaro Siza Vieira (1992) and Eduardo Souto de Moura (2011).

${ }^{11}$ Lucius Annaeus Seneca, stoical philosopher of Iberian origin (born in Córdova), lived between $4 \mathrm{BC}$ e $65 \mathrm{AC}$, having an important impact throughout his life on Rome, mainly from Nero's government on, being his preceptor and who later on would be invited to commit suicide. 
on it ...) and the imposed form to each object" (Seneca, $64 \mathrm{AC})^{12}$. Seneca finds in the primacy of causes similar principles to those dictated by Vitruvius.

Firmitas (solidity and durability) to which built things must be obliged to, derives from the domain of matter; utilitas (utility or convenience of things) will be in the functional form imposed to each object; venustas (beauty and pleasantness), qualities undoubtedly resulting from the artist's (or craftsman's) transformation work, enunciate beauty as the transformation of rough into refined. We can thus identify a certain similarity between Aristotle's causes (translated by Seneca) and Vitruvius' conditions, the first ones referring to the object identification (craftsman, form and matter) and the second ones to its qualification (beautiful, appropriate and safe).

\section{DESIGN'S ONTOLOGY VITRUVIUS, SENECA, BONSIEPE AND PROVIDÊNCIA}

Assuming architecture as a design's ancestor and observing it from an ontological point of view, we can infer the design practice as resulting from three intervention orders:

The one from the draughtsman (that presents himself as an individual or collective author); the one from the programme expected by the target (presented as a set of expectations concerning the functional performance, by eventually adjusting it to the market); the one from the available technical means (presented as the material and technological domain necessary to its production).

2000 years later, one does not glimpse a radical difference ancient and modern artifacts. What is the meaning, for contemporary design, the domain of beauty, functionality and resistance?

Framing Beauty in the post-modern background, of an aesthetic achievement from individual experience, beauty is the exercise of freedom translated by the programme of form, that is to say, the artifact's rethorical domain designed by its author. An authorship brand, certainly, but that is, mainly, a creative manifestation of style as a metaphor (historically engaged) erected for perpetuating life (overcoming end and oblivion).

For that reason the forms of beauty open themselves to such different and contradictory programmes as the ones with a beauty through sublimation, catharsis or difference. If the author's domain is (in its etymological origin) the one from the roman auctor (deriving from augeo, related to "increase"), that is to say,

12 SÉNECA, Lúcio Aneu. Cartas a Lucílio. Lisboa: ed. Fundação Calouste Gulbenkian (2009). ISBN: 9789723105360. 
the one who dilated the empire's territory, the author should be viewed as the one that invents new domains for design. But the author is also the one confronting himself to his death sentence, the one witnessing and overcoming his death sentence. A device, as identified by Michel Foucault and explained by Deleuze ${ }^{13}$, whilst a machine to enable to see and to talk, enunciation system that from a "fracture" translates itself into knowledge, power and subjectivity.

Functionality is the programme attributed to the efforts of drawing, its practical value, the resolution of a certain problems or necessities set, aiming the satisfaction, the confort or the exceedance of the user, frequently required by the client. The project's programme involves concerns with its target and, in that sense, represents the user, leading us to question the limits of that service, if addressed to society or to the market, if addressed to its economic exploitation, if for its social protection.

Questions on the programme direct the project towards the other, convene him, opening up an explosive discussion on the social role of design. Market economy has been placing the consummer in the centre of its concerns. Some authors condemn darwinistically to residual uselessness all the drawing (of artifacts) that does not respond to the market's requirement. But how can the market aim for what it does not know? And proposing itself to solve the market problems, will not design remain hostage from a competition between similars, limiting difference only as far as the price is concerned?

For the progress in the qualification of consumption, for the progress of design in its own innovation, design should create new problems to the market, instead of submitting itself to its demands. In any case, practical functionality, or the programme, intend design, ascribe to it a social or commercial intention, that finds in sociology and marketing privileged partners for its dissemination. Sustainability, accessibility and social innovation have characterised design's programming agenda, substituting the obsolescence of others, such as ergonomy, fashion or identity.

Finally, Durability concerns the technological domain. The technology that allows edificating things. Technology determined the format of things before the invention of drawing. That was the big revolution operated by Drawing classes in the 16 th century, founding Academia ${ }^{14}$ by liberating form from the technological

${ }^{13}$ DELEUZE, G. O que é um dispositivo, in DELEUZE, G. (1996). O mistério de Ariana (tradução e prefácio de Edmundo Cordeiro). Lisboa: Ed. Vega - Passagens. In http:// www.uc.pt/iii/ceis20/conceitos_dispositivos/programa/deleuze_dispositivo

${ }^{14}$ In the 16th century, St. Luke Academy was founded in Rome in 1577 (14 years after 
constraint imposed by artesanía _ in traditional technicality, in handcraft, there is no drawing but moulds applied on models through traced design, likewise on tailoring. It was drawing that, on behalf of desire, implied the overcoming of technology, releasing it from tradition. If through technology the humankind was released from natural constraints (namely from the dependency on irregular energy sources), it was also technology that imposed the insurmountable and present domination framework; we live, nowadays, more dependent than ever on technology. Drawing is (as it has always been) a product from technology, submitted to its rethoric. The introduction of vectorial machines for drawing, such as the Freehand (in the 1990s of the last century) or the Adobe Illustrator (that survived the previous one), contaminated design's form, reifying and massifying it.

In the last 20 years, digital technology has played a dominant role on mobilizing economy, sexual and social reorganization and the anthropological representation itself. A technology that, the more advanced, the more invisible becomes, has turned to deeply dominate human life.

What is, therefore, technology to design? Where does its manifestation root itself? Technology is in the origin of humankind's invention. I say invention because humankind is, as Ortega and Gasset refers, that animal that, because he does not exist yet, he is looking forward to being, building itself. An entity whose being consists, not of what it is already, but of what it is not yet, make of it a pure imagined possibility ${ }^{15}$ (Ortega and Gasset, 2009).

Technology is, has been, the tool for implementing that pure imagined possibility. Which technology has humankind built? Undoubtedly, the word or, before it, drawing, allowed humankind to present itself (to become present). If tech-

her congener in Florence), associating artists to overcome the simple handcraft, through drawing and drawing from a living model. St. Luke Academy had notable teachers such as Bernini and Pietro Francesco Alberti who, in 1625, presented this space as a workshop, as a model to the other drawing classes that still function in the Fine Arts Schools (luminous spaces, with plaster models of busts, body members, skeletons and skinless models, where one would draw on easel, with charcoal or graphite, the naked model to learn both the visual language and the human anatomy). In the 18th century, by order of D. Maria I, João Carlos de Bragança ( $2^{\circ}$ Duque de Lafões) established in Lisboa, in 1779, the Academia Real das Ciências de Lisboa, devoted to the promotion of History, Letters, Sciences and Economy. In the 19th century, by decree of D. Maria II, the Academia Real de Belas-Artes was created in Lisbon, in 1836, nowadays a public institution, under State supervision and with the task of defending arts.

15 Ortega and Gasset, José. Meditação sobre a técnica (tradução de Margarida Amoedo). Lisboa, ed. Fim de Século, 2009. ISBN: 978-972- 754-265-9. 
nology released humankind from its natural constraints, it also created nem technical ones, making him forget the being (Heidegger). If technical language transforms the human being into a thing, alienating himself, the poetic language, unveiling truth, might reconciliate him with the being. But how to assure the poetic language alternative to the technical object constitution? How to balance poetry and technology? Poetry, in its interpretative accuracy, interprets not only the purposes (goals), but also the means (technology), giving origin to novelty; that is a condition of existence that cannot be forsaken.

Using Vitruvius' and Seneca's thinking in present design achievements, the ontological model seems quite consistent, observed by its intervenients: Author (beauty, craftsman, draughtsman), Programme (utility, target, motivation) and Technology (resistance, matter, instrument).

Let us admit, therefore, that authorship, programme and technology constitute themselves as three drawing production agents (Design), invoking aesthetics, aesthetics and technique under the common goal of the shape design; if that is so, also in the shape the three dimensions on its origin - poetic, social and technological - will converge.

This ontological principle was applied to the teaching structure of design at the University of Aveiro (1st training cicle, degree), therefore motivating a polysemic experience on the learner, creating a wide field of possibilities approached differently in each one of the 3 training years, evolving from the freedom of the author (aesthetic reference frameworks), to the programme constraint (accomplished in conjunction with companies), going through knowledge on technologies (viewed as creative means of production), thus constituting itself a design experimental lab. In each one of the three years of the training cycle the three agents are questioned: Who does it? How? And why? (Branco and Povidência, The Design Journal, 2017).

Possibly motivated by the present perplexity of Design in its endless extension of hybrid combinations, London Design Museum has also felt the need to bring more clarity and consistency to Design culture, confirming our design ontological thesis through the tripartite organisation of its permanente exhibition, divided into designer, user and manufacturer.

"Design is the product of an intersection between the three key participants of the designer, user and maker. [...] Generally speaking, professional designers respond to briefs given by manufacturers who are influenced by production processes and commercial imperatives" (Newson, Suggett and Sudjic, 2017, p. 7).

Gui Bonsiepe also suggests an ontological structure for Design (Bonsiepe, 2015). According to him, in the design the user, the task and the tool are integrated, as opposed to the model we defend, structuring design polarized by the author, the programme and the technology (Calvera, 2003). 
Acknowledging the evidence of the evidence of the similarity between technology and tool and between programme and task, we identify the cleavage of user instead of author proposed by Bonsiepe. Bonsiepe will, therefore, place the market in the centre of the decision-making process about the shape, dismissing the author, renouncing to his interpreter role on the project, not inviting him to execute the design as his, in the first person, but sacrifying the individual (author) for the sake of the collective (market). By doing it, the designer will renounce to any moral interpretation (or ethical responsibility), formulated from his own consciousness, as existential knowledge.

This is, as I see it, a relevant point on the designer's mediating role. He is hired to do this and that, to solve this or that problem. But should not he be charged for his responsability on what he does? On the consequences of what he does?

Noticing that sometimes we are invited to renounce to the moral decision on the shape, and acknowledging design as a moral decision about the shape of beauty (idea quoted from the plastic artist Álvaro Lapa ${ }^{16}$ ), the thought of Hannah Arendt ${ }^{17}$ on the nazi officer's trial "Eichmann in Jerusalem" comes to me:

"Eichmann's problem was exactly that many were like him, and many were neither perverts, nor sadistics, but were, and still are, terribly and frighteningly normal. From the point of view of our institutions and our moral judgment standards, that normality was far more dreadful than all the atrocities together", because that indifference before the other was grounded in the renunciation of consciousness, constituting in itself the major crime against humankind.

Awareness on the shapes of what we do, apart from a moral condition, should also be matter of research, discussion, study and comprehension, that is to say, matter of knowledge, in order to formulate the answer to the question: Which Man designs your forms? Which Man designs himself on your Design?

\section{RESEARCH IN DESIGN}

Turning to the ontological consideration, generated from the author, the programme and the technology, we will inevitably build a triangular relationship,

${ }^{16}$ DIONÍSIO, Eduarda; FARIA, Almeida; MATOS, Luís Salgado de (org.) (1968). Situação da arte: inquérito junto de artistas e intelectuais portugueses. Mem Martins: Publicações Europa-América.

${ }^{17}$ ARENDT, Hannah (1999). Eichmann em Jerusalém: um relato sobre a banalidade do mal (Parte II) (tradução de José Rubens Siqueira). Rio de Janeiro, ed. Companhia das Letras. ISBN: 978-85-7164-962-0. 
where Design is generated. Design generated in this field of tripartite influence will also acquire different identity according to its proximit towards each one of the vertexes. In its edges, however, two-way relationships are produced between each pair of vertexes, generating exterior mediation surfaces with the knowledge from other areas:

In the connection between the Author and the Techonology, Art is generated, interpreting technology from itself, declining the Programme and any externally imposed functionality;

In the connection between the Programme and the Technology, Engineering is generated, declining the Author, motivating itself through the objectivity of ergonomic suitability and productivity optimization;

In the connection between the Author and the Programme, Management is generated, declining Technology to focus on the leadership of social goals, politically and commercially recognizing them.

With no simultaneous presence of the three drawing agents (author, programme and technology vertexes), the result will inevitably refer to one of the three "reductions" (art, engineering and management edges). Therefore, it will be relatively easy to find a justification for the Design scientific partnership with Art, Engineering and Management domains.

The question is, therefore, grounded in the historical process of design's international dissemination. In Southern Europe the trainging in design is, at the beginning, integrated in the Fine Arts Schools. But from Ulm's german school on, a design's technological culture that positions it near to engineering has spread. In many schools all over the world design was also born associated to Management, whether as a marketing instrument, whether as a sociological tool at the service of social and political activism.

In these three big generating centres of design one can still acknowledge its subcultures - communication Design (invoking art), industrial Design (invoking engineering) and service Design (invoking management). It seems natural that these design elective affinities imply the research and produced knowledge diversity, with implications for the polysemic claim of a science of design.

In that sense and reflecting on research as a source of innovation in design, we observed that doctorates in design accomplished in Portugal (Félix, 2013) reveal in more than two thirds (67\%) the category that Frayling (1993) identified as "into design" (from external scientific contributions, coming from history, sociology or engineering...) and that only $15 \%$ could get close to the "for design" category, directly coming from its project-oriented activity and resulting in the drawn object. 
According to Vasco Branco, two contributions might be in the origin of this evidence: the training of the first design doctorate advisors and the lack of concern from industry towards this field of knowledge, therefore infering that the impact of research in design on professional, economic and social activity is paradoxically residual or even inexistent in Portugal (Branco and Providência, $2017)^{18}$.

If there is no doubt about the benefits that Design experienced with the external contribution from other fields of knowledge, one could also question if it should not attach more relevance to its own designing epistemology, namely through the deepening of a research on project, turning project into its own knowledge production lab, though encouraging the convergence between design's theoretical and practical dimensions on the same object.

\section{PHENOMENOLOGY OF DESIGN DORST, CROSS AND TILL}

Dorst $\mathrm{t}^{19}$, in $2016^{20}$, came out in favour of the convergence between design's theory and practice, through the creation of what he called academic Design. Dorst's academic Design is grounded in the observation of three problems:

Theory in design is disconnected from its practice (neither serving it nor being instrumentally recognized by this last one);

Theory in design presents itself internally diffuse and unclear (opening itself systematically to the extension of new domains);

Theory in design has not achieved the impact that one would expect among the designers' community (that does not recognise to it an effective contribution to design's innovation and development).

To rehearse an integrated and convergent response through such "academic Design", Dorst identifies the privileged resource to knowledge on three academic and professional domains: the theory of Art, Marketing and Management.

The doubt formulated by Dorst on the importance of theory about design's practice does not seem unusual when we notice the architectural innovation pro-

${ }^{18}$ Branco, V., Providência, F. Design as Cultural Mediation between Matter and What Matters, The Design Journal, 21(1), p.1-9, November 2017. In http://www.tandfonline.com/eprint/sTxE4pN3VHW3fcikFAWu/full

${ }^{19}$ Kees Dorst, design university professor in Sydney and director of the design research centre in Eindhoven, has been studying with all its relevance the traditional divorce between design's practice and theory.

${ }^{20}$ Communication at the congress Design, research and society, in Brighton (2016). 
duction from awarded architects such as Álvaro Siza or Souto de Moura, not benefiting from the knowledge produced in any architecture research centre (apart from the tacit research directly undertaken in their own offices and headed by themselves).

However, the model of an academic Design proposed by Dorst, seems too committed to management, lacking the technological and artistic dimension.

Responding to the definition of what might be the research (knowledge production) in design project, the ethnographic observation of its creative practice (also predicted by Frayling) will gain relevance, to the comprehension of design's creative process. As Lino Cabezas from the University of Barcelona argues, the research in design and its theoretical production should result a posteriori and not a priori from design (maybe to preserve contributions from the unconscious that, otherwise, would be censored by consciousness).

Design's abductive character (always evolving through hypothesis), founded in the empirical and heuristic practice of problem-solving through drawing, will gain an enourmous potential with the integration of a more critical dimension, but that cannot stay allof nor differ from the designing act, so that it does not run the risk of submitting itself, through practice, to a mere illustration of theory.

Joana Quental ${ }^{21}$ reflecting on design's methodology, takes the question submitted by Alain Findeli, asking herself: does the design subject have a specific scientific and/or academic status, sufficiently distinct from other subjects so that it demands and justifies the use of specific methodologies to conduct its research? (Findeli, 1999:1).

Nigel Cross, contemporaneously with Findeli, will publish in the same year a possible answer, identifying in the designer a particular manner of reasoning, the origin of a design's natural intelligence, capable of distinguishing it from other forms of thinking (Cross, 1999), what would constitute the ontological root of its scientific affirmation. Briefly, Cross suggests that specific knowledge forms of design might have three origins, centering themselves in people, in the processes or in the products.

Considering people (and the human mission of designing artifacts), research will include empirical studies on the nature of that skill and the design teaching and learning methodologies.

${ }^{21}$ Joana Quental PhD is designer and professor at the Doctoral Programme in Design from the University of Aveiro, assuring its vice-direction and the Curricular Unit of Methodology. 
Considering processes, research focus should be attributed to doing, to the design's techniques, strategies and methodologies.

But, from the products point of view, research will fall on the study of forms and materials that configure the idea and, consequently, design's achievements as ideal manifestations (not only because they were conceived, but also because all forms are, in themselves, ideas).

From here Cross will deduce a characterizing taxonomy of research in design, enunciated by the domains of the epistemology which he called "designerly ways of knowing" (study of the ways to knowledge), enuntiated by the domains of epistemology (about the way the designer carries out his work), praxiology (about practices and processes) and phenomenology (dedicated to the study of artifacts' form).

According to Cross, we therefore consider Phenomenology as the research for the production of knowledge in Design centred in the convergence of a thought of, and in the designing practice (drawing), convergent with Houaiss ${ }^{22}$ etymological definition, when considering "any theoretical formulation that aims to highlight the living experience on subjectivity, to the detriment of predefined principles, theories or values and, therefore, the process that elevates itself from the individual and apparent sensations to the true and universal reason".

Phenomenology, whereas the philosophical study of consciousness and its objects, applauds the way through which knowledge of the world is accomplished through each person, instead of the (inaccessible) world's existence in itself. For that reason the impact of the diversity of authors (individual authors) is highlighted, expanding, through their objects, design's consciousness about itself.

However, according to Jeremy Till ${ }^{23}$, reflecting on his text "Three myths and one model" 24 (2017) about the research in architecture (that we will use here applied to design), there are three frequent misconceptions related to research in design through project.

The first one refers to the conviction that design is exclusively design, shutting itself until its own marginalisation. Design will, then, become more and more irrelevante or even irresponsible, risking to be ignored.

22 "Fenomenologia" in HOUAISS, Antônio (2001). Dicionário Houaiss da Língua Portuguesa. Rio de Janeiro, ed. Objetiva.

${ }^{23}$ Jeremy Till (1957-), architect, investigator and professor at Central Saint Martins and Pro Vice-Chancellor of University of the Arts London.

${ }^{24}$ TILL, Jeremy (2008 1st edition). Three myths and one model. Building Material Vol.17. Dublin, (Published here under a Creative Commons, non-commercial, no derivatives license), pp. 4-10. 
The second one, by opposing the first one, claims that design is no-design, aiming to conquer its credibility near other more recognized subjects, but that dependo $\mathrm{n}$ other intellectual paradigms. When turning to others, design dresses a methodological straightjacket, forgetting its own nature.

The third one argues that drawing is researching, acknowledging it each design's uniqueness and originality the original production of knowledge. But knowledge in design, investigation the definition on "research" from Bruce Archer is, according to Till, the "transmissible knowledge", for which reason artifacts, in themselves, will not provide sufficient proof. In order to promote Design's progress, it will be necessary to understand its processes and question the objects' life after its conclusion. But by doing it through speech, will not the author hide his own origin (as the psycho-traumatized patient), that way calling the comprehension of the phenomenon, the analysis of his own speech?

In the model proposed by Till, Design should realize its own basis and specific knowledge procedures. Design's comprehension into a qualitative or quantitative activity is not easily categorised, and therefore should be regarded as a synthesis of a great variety of intelectual approaches. Design should learn to communicate its tacit research, accomplished through its designing practice, but in a way that does not compromise the value of intelectual property from its own individual practice.

Design can, and must be, a research subject with its own rights, acknowledging the Academia universally accepted criteria but, simultaneously, applying them in an appropriate manner to the questions it has to solve, from conception to mediation through drawing (shape and process).

As previously referred, it is possible, nowadays, concerning research in design to distinguish three large mediation domains: services' mediation (motivated by management), product's mediation (motivated by engineering) and communication's mediation (motivated by art), though originating service design, product design and communication design.

Service design to social intervention is the one, presently, getting more media visibility in Design's culture. Very informed through sociology and management contributions, namely in innovation and social accessibility, design management and design thinking, in this domain, as Ezio Manzini ${ }^{25}$ observes, design should no longer continue to feed industry, but focus itself on redesigning society for a

${ }^{25}$ The reference, in this context, to Ezio Manzini (recognised design professor and thinker from the Milan Polytechnic) is not based on any specific quotation, but in his general thinking. 
more sustainable performance, privileging the territory's management. By opposing itself to the traditional economic structure, service design has been creating differentiation mainly through social innovation, frequently forgetting its own creative culture, or creating new associations with low technological (handcrafted) producers or even ou validating autoproduction.

Simultaneously, product (or industrial) design keeps on feeding the big production industry of marketable goods (nowadays shifted to the East and founded on digital), even if observing natural phenomena in a more attentive way and, therefore, electing bio-mimetism as the protagonist of the artificial, adopting the innumerous solutions offered to complex problem-solving and generically promoting the reduction of the resistance between natural and artificial (between body and prosthesis), but regarding market as its future decision-maker. In this perspective and as Di Bartolo ${ }^{26}$ points out, design is submitted to the social darwinism from which the future of drawing will, inexorably, depend.

In a third domain, communication design inherits remote expressions from graphic design, privileges artifacts' cultural mediation, destinating them to the construction of (new) meanings, that design will, ultimately, accomplish to find a global sense to its efforts. Aesthetic dimension of an author's poetry, away from formalities and ornaments, does not respond to the market's needs, but offers it new needs. As one can recall from Andrea Branzi ${ }^{27}$, design is a metaphorical resource that, besides its practical function, does not abandon the symbolic function with which interprets world and life, though inviting the own existence as difference.

In these innovation areas we review the three generating centres observed in design's ontology: the technology (nowadays stated by digital as the protagonist of the interactive experience), the programme (headed by the sustainabiliy and ecology social dimension) and the autor (aesthetic interpreter of the world using metaphor to produce new meanings).

Design therefore appears as a cultural mediation activity that translates into the drawing of artifacts, devices and services the process of the historical evolution from industrial Design (product) when the 19th century turned, the emer-

26 The reference, in this context, to Di Bartolo (recognised design professor and thinker from the European Design Institute, Milan) is not based in any specific quotation, but in his general thinking.

27 The reference of Andrea Branzi (recognised design professor and thinker from Milan Polytechnic, co-founder of Domus Academy) is not based in any specific quotation, but in his general thinking. 
gence of communication design by the middle of the 20th century and the gradual hegemony of service design (mainly in digital support), taking place over the last twenty years from the 21st century. The different fields of design persist simultaneously, translating features, at times contradictory, from a commonly shared culture, centred in the ambition of contributing through material culture to the common good in progress.

But might such distinctive expressions of Design question us if there is a common denominator to their practice? If their practice will constitute disciplinar support? Or if we acknowledge a methodology that supports a science of design? Is design a methodology, a way of achieving a goal, as Marco Sousa San$\operatorname{tos}^{28}$ (1999) stated days before the first biennale Experimenta (Público, 2017) ${ }^{29}$ and, consequently, an operative instrument or, like art, will constitute and end in itself?

It is importante to ask and understand what designology (or science of design) means, acknowleding humbly to Drawing the device of formulating, understanding and communicating the ideas and the inventions of what we want to do and be.

\section{FOR A DEFINITION OF DESIGNOLOGY30}

Thinking from Kuno Prey ${ }^{31}$, I ask myself: is Design a subject ${ }^{32}$ or a science ${ }^{33}$ ? If the subject brings us to the idea of behavioural order, to the domain of methods that ensure a particular technical outcome translated into doing (the reality), science brings us to the methodology with which we direct the spirit when ques-

${ }^{28}$ Marco Sousa Santos (1962-), designer, professor, entrepreneur and animator of design culture, founder of the Experimenta design (1999-2017) biennale.

29 "ExperimentaDesign: o fim da bienal, 18 anos depois", by Joana Amaral Cardoso, In revista Ípsilon / Jornal Público, https://www.publico.pt/2017/09/30/culturaipsilon/noticia/experimentadesign-o-fim-da-bienal-18-anos-depois-1787164 (consulted on August 13, 2018).

30 “Contributo para a definição de uma ciência do design", Francisco Providência I ed. facebook | 16 junho 2018 in https://www.facebook.com/providenciadesign/ posts/1531249746979281

${ }^{31}$ UD18, meeting of doctorate students in Design, Universidade de Aveiro, 2018.

32 A Subject is a set of regulations from resulting from a certain knowledge, or know-how, intended to maintain any corporation at a good fuctional order.

${ }^{33}$ A Science is a rationalised, experimented and universally communicable knowledge, on a specific theme, obtained through its own methodology. 
tioning reality, translated into thinking (the truth). Ultimately, the "subject" does the reality and the "science" thinks the truth. But if design thinks the truth (through its authors) doing reality (through the accomplished drawings), then design "thinks by doing" and, consequently, its science will be the poetics (poet is the one who does).

Foreseeing Design from this point of view, we might be tempted to think that Design is a subject, once the product of its knowledge is never universal; that is to say, the thought truth is always associated to each one of its agents and circumstances. But if we think that that one is the condition of interpretative truth of Design, then it will not be also possible to elect a corporative method, because we aknowledge the existence of an intrinsic methodology to each agent (author) and, consequently, of many methods to do it.

In design's Science, when convoking the indivual as an agent, we will lose the universal truth to find the polysemic diversity of a way of thinking, translated into each act of doing. That is why design's methodology will be the set of all invoked methodologies by all the designers. This will be its phenomenological advantage, by retrieving the subjective legacy as knowledge. In that sense, design's authorship convokes the existence of its agent, its subjectivity, as a production and moral guarantee device (distinguishing good from evil, from the own existential experience).

By conceiving the project from itself (author) and putting itself in the other's shoes (programme / user), its inscription and cumplicity on being there, in a social situation, will be guaranteed. But how to guarantee that its contribution escapes to the frivolity reifying vortex? How to assure that it escapes from the condemnation to repetition (inauthenticity) with which it is polluted by material culture? Through the confrontation with nothingness, that is its consciousness of time. "Nothingness" guarantees, will guarantee, truth's unmasking and the convocation of difference (Heidegger).

Taking for granted that the design's theme is the designation or drawing of the form, its formulation will then be produced in its act of doing (drawing), what turns design into the science of poetics (or poiesis). But the aim of doing-thinking design is engraved in the operated relationship, in the transforming expectation of that action. If Design conceives a wine label, a bicycle, a brand or a service, it operates a mediation and the specificity of its knowledge will be, precisely, that one: "to mediate". By mediating, design has been contributing to the human functionalization, transforming beings into things, men into consummers and society into market, in a big chain of causalities that usually start from the individual annulment or his apparent exaltation for pseudo-freedom of choice that will subjugate him to technology, exchanging freedom for survival, or a dependency for a bigger one. 
If in that mediation, knowledge would result conditioned by the operative matrix from its own agent, then that would be a cultural mediation.

Thus and summaryzing, design is, in the European tradition, drawing of cultural mediation, or drawing of cultural mediation artifacts, devices and services.

While drawing of cultural mediation, design presupposes a technology (operative means) and an agent (draughtsman), but also a goal (function): design actuates.

We can then add to design's formulation: drawing of cultural mediation for the artificial (world's transformation) _ though it might be redundant, once all culture is already a construction of the artificial.

Design will then be defined as drawing of artificial mediation artifacts, devices and services. But admitting its contribution for authenticity _ in the condition of turning the being present, as an epiphany of freedom and accomplishment _, its plan shall subordinate practical function to symbolic, changing the euphoria of interventive exaltation for nothingness.

In that condition (and in that one exclusively) Design would become: drawing of artificial mediation artifacts, devices and services for nothingness. That is its wisdom and its major difficulty, once "nothingness" is not the indifference of result, but exactly its opposite, brings the novelty of difference.

But can we change the desire for repetition (or "happiness" as Kundera ${ }^{34}$ called it), for the sacrifice of differentiation (resistance against indifference and innovation condition)? Maybe. That is our thesis, a design informed by the life of its own author.

\section{ACKNOWLEDGEMENTS}

To professor Guilherme Santa Rosa, Universidade Federal do Rio Grande do Norte and Sociedade Brasileira de Design da Informação - SBDI for the invitation addressed to deliver this communication at Congresso Internacional de Design de Informação, Natal.

To my colleague and friend Vasco Branco, for the fruitful exchanges of ideas motivated by the discovery of Design as original thought that, founded in the

34 "Human time does not spin round in circles, but advances in a straight line. That is why the human being cannot be happy, because happiness is the desire of repetition". KUNDERA, Milan (2017 reimpressão). A Insustentável Leveza do Ser. Lisboa, ed. Bis. 
practice of drawing, aims to contribute to the construction of new meanings.

To my doctoral students Lígia Afreixo e Marlene Ribeiro for the tireless dedication provided.

\section{REFERENCES}

Adorno, Theodor (1970). Teoria Estética. Lisboa, Edições 70, Lda.

Arendt, Hannah (1999). Eichmann em Jerusalém: um relato sobre a banalidade do mal (Parte II) (tradução de José Rubens Siqueira). Rio de Janeiro, ed. Companhia das Letras. ISBN: 978-85-7164-962-0.

Bonsiepe, Guy (2015). Do material ao digital. São Paulo, ed. Blucher. ISBN: 9788521208716.

Branco, V., Providência, F. Design as Cultural Mediation between Matter and What Matters, The Design Journal, 21(1):1-9, November 2017. In http://www.tandfonline. com/eprint/sTxE4pN3VHW3fcikFAWu/full

Cross, Nigel (1999). Design Research: A Disciplined Conversation. Design Issues, Vol. 15, No. 2, Design Research (Summer, 1999), pp. 5-10. Published by The MIT Press.

Deleuze, Gilles, O que é um dispositivo, in Deleuze, Gilles (1996). O mistério de Ariana (tradução e prefácio de Edmundo Cordeiro). Lisboa: Ed. Vega - Passagens. In http:// www.uc.pt/iii/ceis20/conceitos_dispositivos/programa/deleuze_dispositivo

Dionísio, Eduarda; FARIA, Almeida; MATOS, Luís Salgado de (org.) (1968). Situação da arte: inquérito junto de artistas e intelectuais portugueses. Mem Martins: Publicações Europa-América.

Dorst, Kees (2016), Design practice and design research: finally together? Brighton (UK), Design Research: History, Theory, Practice - Histories for Future-focused Thinking. In http://www.drs2016.org/212/

Erlhoff, Michael and MARSHALL, Tim (eds), (2008). Design Dictionary, perspectives on Design Terminology. Berlin, Birkhäuser Verlag.

Félix, M. J. (2013). Contribution for a Strategic Vision of Research in the Area of Design in Portugal. PhD Thesis (in Portuguese), Faculty of Architecture of the University of Lisbon.

Findeli, Alain (guest editor) - re:search. Design Issues: 1999.

Frayling, Cristopher (1993). Investigação em Arte e Design (tradução de Rui Costa), Royal College of Art Research Papers Volume 1 Number 1 1993/1994. Londres, ed. Royal College of Art Kensington Gore London SW7 2EU United Kingdom. ISBN: 1 874175551.

Holanda, Francisco de (1985). Da Ciência do Desenho. Lisboa, ed. Livros Horizonte.

Houaiss, Antônio (2001). Dicionário Houaiss da Língua Portuguesa. Rio de Janeiro, ed. Objetiva. 
Margolin, V. (2013). “Design Studies: Tasks and Challenges”. The Design Journal 16 (4): 400-407.10.2752/175630613X13746645186043

Ortega and Gasset, José (2009). Meditação sobre a técnica (tradução de Margarida Amoedo). Lisboa, ed. Fim de Século. ISBN: 978-972- 754-265-9.

Providência, Francisco, Algo más que uma hélice, in CALVERA, Anna (ed.) (2003). Arte? Diseño? Nuevos capítulos em uma polémica que viene de lejos. Barcelona, ed. Gustavo Gili. ISBN: 84-252-1543-9.

Providência, Francisco (2000). Directório de Design 1999-2000. Lisboa, Centro Português de Design. ISBN: 972-9445-08-7.

Providência, Francisco (2012). Poeta, ou aquele que faz - a poética como inovação em Design. [S.1.]: Universidade de Aveiro.

RUA, Maria Helena (1998). Os dez livros de arquitectura de Vitrúvio (Corrigidos e traduzidos recentemente em Português, com notações e figuras). 1. ed. Lisboa: Departamento de Engenharia Civil, Instituto Superior Técnico. ISBN: 129.248/98.

Séneca, Lúcio Aneu (2009). Cartas a Lucílio. Lisboa: ed. Fundação Calouste Gulbenkian. ISBN: 9789723105360.

Till, Jeremy (2008 1st edition). Three myths and one model. Building Material Vol.17. Dublin, (Published here under a Creative Commons, non-commercial, no derivatives license), pp. 4-10.

Worringer, Wilhelm (1908 1997). Abstraction and empathy, a contribution to the psychology of style (tradução do alemão por Michael Bullock). Chicago, ed. Elephant Paperbacks. In https://monoskop.org/images/a/a2/Worringer_Wilhelm_Abstraction_and_ Empathy_1997.pdf 
382 Selected Reading 